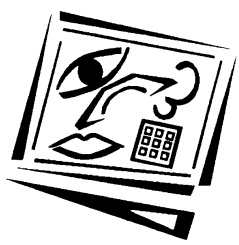

\title{
Learning about problem based learning: Student teachers integrating technology, pedagogy and content knowledge
}

\author{
Hyo-Jeong So \\ Nanyang Technological University \\ Bosung Kim \\ University of Missouri
}

\begin{abstract}
What should constitute knowledge bases that we expect our future teachers to gain related to pedagogically sound technology integration? Employing the Shulman's teacher knowledge base as a theoretical lens, this study examined the complexity of pre-service teachers' technological pedagogical content knowledge (TPCK) in the context of integrating problem based learning (PBL) and information and communications technology (ICT). Ninety-seven pre-service teachers in this study engaged in a collaborative lesson design project where they applied pedagogical knowledge about PBL to design a technology integrated lesson in their subject area of teaching. Data were collected from two sources: survey and lesson design artifacts. Data analyses revealed that while participants had theoretical understandings of pedagogical knowledge about PBL, their lesson designs showed a mismatch among technology tools, content representations, and pedagogical strategies, indicating conflicts in translating pedagogical content knowledge into designing pedagogically sound, technology integrated lessons. The areas that students perceived to be particularly challenging and difficult include: a) generating authentic and ill-structured problems for a chosen content topic, b) finding and integrating ICT tools and resources relevant for the target students and learning activities, and c) designing tasks with a balance between teacher guidance and student independence. The present study suggests the potential of two explanations for such difficulties: lack of intimate connection among beliefs, knowledge, and actions, and insufficient repertoires for teaching with technology for problem based learning.
\end{abstract}

\section{Introduction}

As new advanced technologies have come to our classrooms, there is increased interest in the essential roles and qualities of teacher knowledge bases necessary for successful technology integration. However, it has been suggested that many teacher education programs have not been preparing teacher candidates adequately to integrate technology, and many teachers in schools are reluctant to use technology for teaching and learning (Fishman \& Davis, 2006; Moursund \& Bielefeldt, 1999; Willis \& Mehlinger, 1996; Zhao, Pugh \& Sheldon, 2002). One of reasons for this phenomenon is that student teachers have very little knowledge about effective technology integration, even after completing courses about instructional technology (Hew \& Brush, 2007; Vannatta \& Beyerbach, 2000). Although technology courses have offered a variety of technological tools and provided opportunities to learn and practice technical skills, it has been pointed out that mere exposure to a number of technical tools does not necessarily mean that pre-service teachers can develop abilities to 
design successful, technology integrated lessons. Conversely, focusing solely on pedagogical issues without teaching foundational technical knowledge and skills may lead to difficulties in designing and delivering technology integrated instruction (Mehlinger \& Powers, 2002). Taken together, these observations may indicate that there is a need to understand how teacher education programs could be designed and implemented to provide pre-services teachers with a balance between pedagogical knowledge and technological knowledge.

In the present study, employing the Shulman's teacher knowledge base (1986) as a theoretical lens, we consider that one possible explanation for the lack of technology integration is related to technological pedagogical content knowledge (TPCK). Teachers may have difficulty understanding the complex relationships between technology, pedagogy and content, because these are often taught in isolation in most teacher education programs. Our attempt to address this TPCK issue was to engage preservice teachers in a lesson design project in which they applied pedagogical content knowledge to problem based learning (pedagogy) and technological knowledge of various ICT tools (technology), to create a subject specific lesson package (content). This paper reports on students' perceptions of TPCK and cognitive difficulties as revealed in lesson design artifacts, design, and personal reflections.

\section{Theoretical background}

\section{Knowledge base for teaching}

What constitutes knowledge bases that we expect our future teachers to gain in teacher education programs? Historically, teachers' knowledge bases have focused on two forms of knowledge: content knowledge (what to teach) and pedagogical knowledge (how to teach). To teach biology, for instance, one should have content knowledge on several subject topics covered in a biology curriculum and pedagogical knowledge on theories and methods related to learning, assessment, and classroom management. About two decades ago, Shulman $(1986,1987)$ criticised traditional teacher education for treating content knowledge and pedagogical knowledge as separated domains of teacher knowledge bases. He argued that different subjects have different content structures, so that teachers should have an in depth understanding of how content knowledge and pedagogical knowledge are inter-related.

For this reason, Shulman (1986) proposed a third form of teacher knowledge, pedagogical content knowledge (PCK), defined as knowledge related to "the way of representing and formulating the subject that make it comprehensible to others... an understanding of what makes the learning of specific topics easy or difficult" (p.9). In addition to PCK, he proposed six broad types of knowledge as the teachers' knowledge base: content knowledge, general pedagogical knowledge, curriculum knowledge, general knowledge of learners and their characteristics, general knowledge of educational contexts (e.g. classroom, school, communities, cultures, etc). Shulman's framework for teacher knowledge highlights the importance of the complex interrelationship between teachers' knowledge about both content and pedagogy, and the need for teachers to learn about variable ways of representing subject matter.

\section{Technology integration}

The theoretical notion of PCK is highly relevant in discussing teachers' knowledge about technology integration. Although Shulman (1986) did not specifically include 
technological knowledge in his framework, technology can play a critical role in representing a certain subject matter to be more comprehensible and concrete, helping students correct their misconceptions on certain topics, providing cognitive and metacognitive scaffoldings, and ultimately improving learning outcomes. Indeed, several researchers have reported positive effects of technology integrated interventions on student achievement in mathematics, science, and other subject areas (e.g., Barab, Thomas, Dodge, Carteaux \& Tuzun, 2005; Barak \& Dori, 2005; Barron et al., 1998; Bottino \& Robotti, 2007; Linn, Clark \& Slotta, 2003; Roschelle, Kaput \& Stroup, 2000; Scardamalia \& Bereiter, 1994; van Aalst \& Chan, 2007; White \& Frederiksen, 1998). For instance, White and Frederiksen (1998) developed a computer enhanced science curriculum named the ThinkerTools Inquiry Curriculum, grounded on the sound pedagogy of inquiry learning and reflective assessment. The ThinkerTools curriculum improved students' science learning and metacognitive thinking strategies successfully.

In another study, Barak and Dori (2005) demonstrated that well-designed project based learning supported by ICT tools (i.e. computerised molecular modeling software packages and the Web) could significantly enhance students' ability to traverse chemistry understanding levels and their understanding of chemical concepts, theories, and the structure of molecules. This ICT based project enabled students to visually construct complex molecular models and supported them to inquire into scientific phenomena and chemistry theories using the Web. Recently, van Aalst and Chan (2007) showed that collaborative inquiry processes using Knowledge Forum, a networked environment for knowledge building, could be effective for students when appropriate levels of scaffolding about portfolio assessment are provided to guide them. These examples of technology research conducted in school contexts clearly suggest that successful technology integration goes beyond simply adding a technology component into subject matter content. Instead, when technology is well integrated into curricular and assessment based on a full consideration of interrelationships among content, pedagogy, and technology, we can expect positive effects of technology integrated lessons on student learning outcomes.

While it is encouraging to see that several previous studies have demonstrated positive effects of technology integrated lessons, as mentioned earlier, many teachers are still reluctant to use technology for teaching and learning (Ertmer, 2005; Hew \& Brush, 2007). According to Pierson (2001), technology integration practices are related to individual teachers' levels of teaching expertise, their definition of technology integration, and pedagogical expertise. This finding supports the connection among teachers' personal beliefs about teaching and learning, pedagogical knowledge, and technology integration. Pierson reported that teachers who effectively integrated technology showed good understandings of unique characteristics of various types of technologies, and were able to draw content, pedagogical, and technological knowledge all together.

Furthermore, it has been suggested that knowing how to use technology for personal use is different from knowing how to use technology for instructional purposes. For instance, Keating and Evans (2001) reported that although student teachers had high confidence with technology for personal use, it did not necessarily mean that they were capable of using technology as a teacher. Most student teachers in their study had an add on technology model, described as the "three computers in the back of the room" (p.1), rather than an integrated technology model, meaning constructive ways of 
using technology for student learning. These previous studies suggest that pre-service teachers need to develop a knowledge base that goes beyond technology proficiency, into learning about how technology can be used for various forms of representations of subject matter.

\section{Technological pedagogical content knowledge (TPCK)}

The aforementioned phenomena on technology integration may indicate that we have not adequately prepared pre-service teachers to form robust knowledge bases for pedagogical content knowledge using technology. This may also imply there has been a great emphasis on what teachers need to learn about a variety of technological tools, but this approach has not been successful in preparing teachers to integrate technology tools into teaching and learning. To further address this concern on teaching technology integration in teacher education, it is important to understand a new framework of teacher knowledge: technological pedagogical content knowledge (TPCK) (Ferdig, 2006; Hughes, 2005; Keating \& Evans, 2001; Koehler \& Mishra, 2005; Mishra \& Koehler, 2006; Niess, 2005). Technological pedagogical content knowledge (TPCK) is grounded on an argument that pedagogically sound applications of technology require teachers to integrate their knowledge on content, pedagogy, and technology, rather than thinking of them as separate domains of knowledge. The conception of TPCK emphasises complex interactions amongst these three elements.

Then, an important question is how to help student teachers develop a firm base of TPCK. It appears that researchers and teacher educators have employed authentic, design based learning where student teachers are engaged in solving authentic problems through design processes (Angeli \& Valanides, 2005; Kearney, 2006; Koehler \& Mishra, 2005; Koehler, Mishra, \& Yahya, 2007). For instance, Kohler and Mishra (2005), and Koehler, Mishra and Yahya (2007) used an approach called Learning Technology by Design, describing it as a collaborative learning context in which a student teacher is engaged to become "a practitioner, not just learning about practice" (p.135). Here, design is both process and product, sensitive to the nature of particular subject matter. Thus, those who are participating in the design process need to rethink about the complex interplay of pedagogy and content, and also affordances of technology to achieve their design goals. Kohler and Mishra (2005) reported that participants who engaged in Learning Technology by Design were able to move from seeing technology, pedagogy, and content as separate constructs towards a more integrated and inter-related construct.

Another important point is that the development of TPCK should be viewed as a long term purpose beyond one single course in teacher education. There is a need for more systematic and macro-level implementation in teacher education programs. For example, Niess (2005) discussed how a particular teacher training program was designed to foster the development of TPCK in an integrated manner, encompassing pedagogy courses, subject specific technology courses, and student teaching. Similarly, Angeli and Valanides (2005) argued that the development of TPCK should be understood under broad contexts of school environments, individual teachers' previous experiences, and epistemological beliefs about teaching and learning.

\section{TPCK: The complexity of believing, knowing and doing}

Some studies have suggested that while teacher cognition affects pedagogical content knowledge, teachers' beliefs may not be easily translated into actual teaching practices 
(Ertmer, 2005; Fang, 1996; Hollingsworth, 1989; Kane, Sandretto \& Heath, 2002). In other words, teachers may have difficulties making intimate connections between believing, knowing, and doing. Theories of action address this inconsistency. Argyris, Putnam and McLain Smith (1985) argued that there are two types of action theories: espoused theories of action and theories in use. When explaining intentions of a certain action, people often tend to respond with their espoused theories of action (explicit), not with actual theories in use. More related to teachers' pedagogical practices, Strauss (1993) suggested that there are two forms of pedagogical content knowledge: espoused PCK and in use PCK. Espoused PCK means knowledge that teachers can speak about teaching and learning, while in use PCK refers to knowledge that teachers actually use for teaching and learning. Strauss argued that knowing how to speak about teaching may be different from how to actually teach in classrooms.

Previous discussions around espoused and in use theories may imply that TPCK should be considered with underlying beliefs and actual practices, rather than focusing on knowledge itself only. For instance, Riel and Becker (2000) found that teacher's use of technology for teaching and learning is closely related to the ability to translate their beliefs into teaching practices: "the most talented leaders with a strong constructivist orientation could not possibly ignore one of the most powerful tools for constructivist learning, and so they would naturally invest their time and energy in learning how to use them" (p.33). However, it is not simple to change teachers' belief systems about teaching and learning. In an ethnographic study that traced three teachers' use of laptop computers, Windschitl and Sahl (2002) found that "the technology did not initiate teachers' movements toward constructivist pedagogy" (p.198). Instead, teachers made decisions to use technology when they could see that the potential of the technology was congruent with their beliefs about learning.

Furthermore, simple views and beliefs about technology integration are often obstacles for the development of TPCK. Angeli (2004) found that pre-service teachers had certain concerns and misconceptions about the pedagogical uses of ICT. In her study, participants expressed skeptical beliefs about ICT integration, such as the following concerns or misconceptions: that ICT a) promotes passive learning, b) isolates children from the social milieu, c) limits children's fantasy and creativity, and d) provides canned knowledge. In summary, previous research suggests that there is a need to address the issue of TPCK for successful technology integration, and personal beliefs about pedagogy and technology should be considered for the development of TPCK.

\section{The present study}

The main purpose of this study was to examine perceived difficulties and concerns that pre-service teachers encountered when applying their knowledge on technology, pedagogy and content to design a technology integrated lesson. A Collaborative Lesson Design was used as a method for investigating pre-service teachers' TPCK. Similar to the Learning Technology by Design approach (Mishra \& Koehler, 2006), the main purpose of the Collaborative Lesson Design approach was to help student teachers engage in the process of making intimate connections among content, pedagogy, and technology, ultimately forming a base for TPCK.

As shown in Figure 1, the pedagogical knowledge examined in this study was problem based learning (PBL). The main task of the Collaborative Lesson Design was to design a PBL package with an integration of various information and communication 
technology (ICT) tools. Content knowledge included english, mathemtics and science which were the student teachers' teaching subject areas. To complete this assignment, student teachers worked in pairs for approximately four weeks. Various terms concerning teacher knowledge used in this study are defined as the following:

- Content knowledge (CK): knowing about what to teach

- Pedagogical knowledge (PK): knowing about how to teach in general

- Technological knowledge (TK): knowing about various technical tools and their capabilities

- Pedagogical content knowledge (PCK): knowing about how to teach particular subject matter content

- Technological pedagogical content knowledge (TPCK): knowing about how to represent subject matter with technology in pedagogically sound ways.

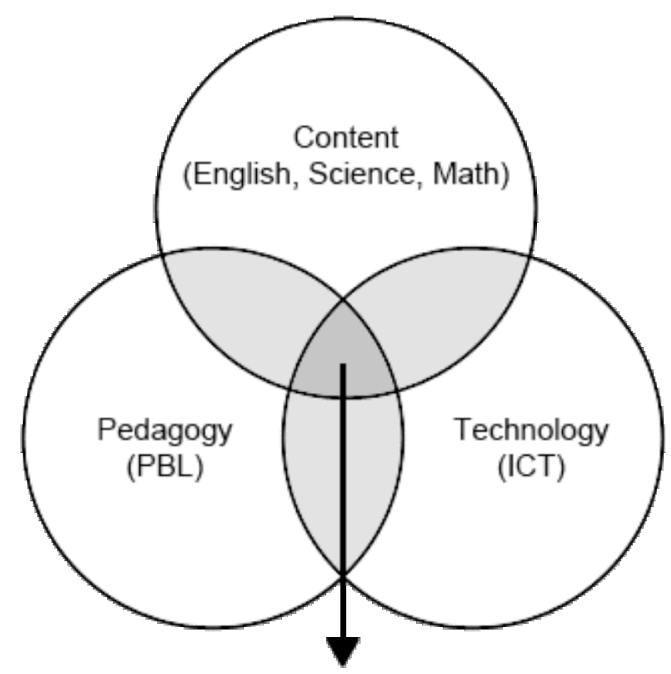

Technological Pedagogical Content Knowledge (TPCIK)

Figure1: The relationship among content, pedagogical and technological knowledge as examined in the present study

\section{Methods}

\section{Context for this study}

The participants in this study were ninety-seven pre-service teachers in Singapore, enrolled in a twelve-week module on the ICT integration for teaching and learning. Participants were from elementary and secondary education programs: fifty $(52.6 \%)$ and forty-five (47.4\%) students respectively (two students did not complete the survey). Regarding genders, sixty-six (69.5\%) students were female, and twenty-nine $(30.5 \%)$ students were male. The average age was 26.4 with approximately 5.25 months of contract teaching experiences in schools prior to taking this module. Regarding previous exposure to pedagogical knowledge on PBL, fifty-two (54.7\%) students indicated that they had learned about PBL in other modules such as educational psychology and mathematics. 


\section{Data collection and analysis}

During the last week of the module, both quantitative and qualitative types of data were collected from two sources: lesson design artifacts and survey responses. First, student projects of the ICT based PBL lessons were analysed to understand how preservice teachers applied their knowledge of PBL and ICT integration into designing lessons on various topics in elementary and secondary curricular. The learning package design was evaluated according to a rubric with the following criteria (each criterion is 5 marks):

- Pedagogical design: (1) Context / Scenario, (2) Process skill / Tasks, (3) Scaffolding / Supporting materials, and (4) Instructions (total: 20 marks)

- Technological design: (1) Incorporation of ICT, (2) Screen organisation, (3) Appeal of display, (4) Continuity / Closure, and (5) Overall technical quality (Total: 25 marks)

Second, a survey instrument containing five demographic items (gender, age, teaching experience, types of teaching subject and school, and PBL exposure) and five open ended items on perceptions on PBL (pedagogy) and ICT (technology) was developed to identify participants' understandings, misconceptions, and difficulties on the integration of ICT and PBL. Sample questions include "how, do you think, the problem based learning help students learn?" and "what do you see as the main strength and weakness of integrating ICT tools into your PBL lesson?" Two coders identified types and frequencies of common themes that emerged from student responses to the five open ended items in the survey. For the focus of this study, the accuracy of content knowledge was not examined. Instead, the representations of content knowledge were evaluated with relation to pedagogical and technological designs in the rubric.

\section{Results}

\section{Technological and pedagogical design}

Lesson design artifacts were analysed to examine how pre-service teachers applied their knowledge on pedagogy, content and technology into design. Table 1 shows descriptive statistics for the learning package designs by 49 pairs. The mean score on their pedagogical design was $3.19(\mathrm{SD}=.37)$, and the mean score on their technological design was $3.27(\mathrm{SD}=.47)$. For the total score of the technological design, there was a significant difference between primary education $(\mathrm{M}=15.54, \mathrm{SD}=.43)$ and secondary education $(\mathrm{M}=17.22, \mathrm{SD}=.49)$ majors, $F(1,47)=6.90, p \& 1 \mathrm{t} ; .05$. However, no group difference was found for the pedagogical design.

Although the average scores on pedagogical design and technological design were very similar between groups, mean scores on each criterion varied. Participants received the lowest average scores on these three criteria: 1) incorporation of ICT ( $\mathrm{M}=$ $2.82, \mathrm{SD}=.67), 2)$ process skill and tasks $(\mathrm{M}=2.86, \mathrm{SD}=.50)$, and 3$)$ scaffolding and supporting materials $(\mathrm{M}=3.00, \mathrm{SD}=.61)$.

Overall, results from analysing lesson design artifacts revealed pre-service teachers' lack of understanding in three major areas:

Technological design

1. Technology integration to better support students' PBL (evaluation criteria: incorporation of ICT) 
Pedagogical design

2. Task design (evaluation criteria: process skill / tasks)

3. Teachers' role as a facilitator (evaluation criteria: scaffolding / supporting materials)

Table 1: Descriptive statistics of learning package design $(n=49)$

\begin{tabular}{|l|l|c|c|}
\hline \multicolumn{1}{|c|}{ Categories } & \multicolumn{1}{|c|}{ Criteria } & Mean & SD \\
\hline $\begin{array}{l}\text { Pedagogical } \\
\text { design }\end{array}$ & Context / scenario & 3.12 & .48 \\
\cline { 2 - 4 } & Process skill / tasks & 2.86 & .50 \\
\cline { 2 - 4 } & Scaffolding / supporting materials & 3.00 & .61 \\
\cline { 2 - 4 } & Instructions & 3.78 & .51 \\
\hline \multirow{2}{*}{$\begin{array}{l}\text { Technological } \\
\text { design }\end{array}$} & Incorporation of ICT & 2.82 & .67 \\
\cline { 2 - 4 } & Screen organisation & 3.35 & .66 \\
\cline { 2 - 4 } & Appeal of display & 3.18 & .70 \\
\cline { 2 - 4 } & Continuity / closure & 3.41 & .64 \\
\cline { 2 - 4 } & Overall technical quality & 3.57 & .61 \\
\hline
\end{tabular}

Note: Each criterion is 5 marks.

Firstly, student teachers tended to use technology as a mere delivery medium rather than an instructional tool supporting cognitive activities. For example, several preservice teachers' PBL lessons consisted simply of a presentation of problem statements and a collection of Internet resources. Secondly, several groups' designs required mostly low order thinking skills leading to one single solution, rather than incorporating ill-structured (i.e. problems with multiple solutions) and higher order thinking skills. Finally, lack of understanding on teachers' roles confused student teachers about how much and what kinds of scaffolding strategies they needed to embed in the lessons. For instance, while some of student teachers pre-specified all the learning activities, some provided little scaffolding so that students would have to find their own resources and answers.

\section{Perceived difficulties related to lesson design}

One might ask whether the problems observed in the lesson design artifacts were related to student teachers' lack of understanding of PBL approaches. Survey data indicated that student teachers had a good theoretical understanding of PBL as an overarching pedagogical approach, but thay encountered problems when applying PBL to design a conten specific lesson. As shown in Table 2, participants were able to identify major characteristics of PBL such as authentic tasks, collaborative learning, student centred learning, and teachers as facilitators. Additionally, pre-service teachers perceived that PBL pedagogy provided students with several advantages including independent learning, metacognitive and critical thinking, problem solving skills, collaborative learning skills, and transfer to real life problems.

Nonetheless, there was a discrepancy between knowing and doing. When applying their pedagogical understanding of PBL, student teachers had several difficulties as observed in the lesson design artifacts. Participants reported the following problematic and difficult areas:

1. Generating problem statements $(n=38)$

2. Integrating ICT tools and resources $(n=30)$

3. Designing tasks to be done $(n=13)$

4. Defining roles of the teacher and learners $(n=11)$ 
Table 2: Pedagogical understanding of PBL

\begin{tabular}{|l|l|c|}
\hline \multicolumn{1}{|c|}{ Question } & \multicolumn{1}{|c|}{ Response } & $f$ \\
\hline $\begin{array}{l}\text { What, in your } \\
\text { understanding, are the } \\
\text { essential } \\
\text { characteristics of PBL? }\end{array}$ & Authentic problems/tasks & 38 \\
\cline { 2 - 3 } $\begin{array}{l}\text { Student centred learning approach } \\
\text { How, do you think, } \\
\text { the problem based } \\
\text { learning help students } \\
\text { learn? }\end{array}$ & $\begin{array}{l}\text { Collaborative learning } \\
\text { their own learning. }\end{array}$ & 29 \\
\cline { 2 - 3 } & $\begin{array}{l}\text { PBL helps students think metacognitively, critically, and/or } \\
\text { creatively }\end{array}$ & 26 \\
\cline { 2 - 3 } & $\begin{array}{l}\text { PBL helps students learn essential skills such as information } \\
\text { Searching skills, communication skills, and technical skills. }\end{array}$ & 24 \\
\cline { 2 - 3 } & PBL help students learn through collaborating with peers. & 13 \\
\cline { 2 - 3 } & PBL helps students apply what they have learned to real life. & 12 \\
\hline
\end{tabular}

Firstly, as PBL is driven by problems, participants felt that creating meaningful authentic problems in their content area was the most difficult task. Those who indicated having difficulties with problem statements stated that they were not sure about (a) how to make problems interesting, authentic, and ill-structured, and (b) what components should constitute problem statements. The following open ended comments indicate this difficulty with problem generation:

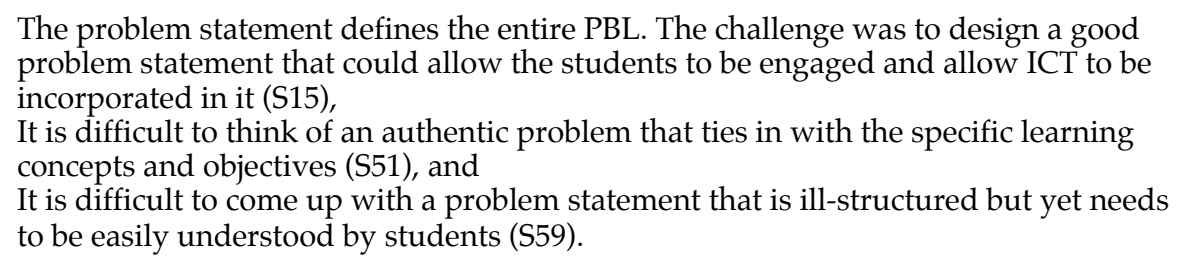

Secondly, personal levels of ICT related skills was another area that students perceived to be challenging. Those who were most challenged by integrating ICT tools and resources attributed their difficulties to no experience or lack of experience in using ICT tools. Some student teachers had to learn new software programs as they had no prior exposure or experience:

I'm not a very IT savvy person. I have to spend a lot of time learning all the basic of various software and applications (including PowerPoint) in order to start off the project. I have ideas but putting them into IT is simply a challenge for me (S37).

It is important to note that students perceived some tension between ICT tools and pedagogical use. That is, even those who had better levels of ICT skills expressed the difficulty of selecting tools and resources appropriate for their target groups of learners and designing learning activities. The following responses indicate this challenge in selecting pedagogically sound ICT tools and resources:

With the myriad of resources available, it was hard for me to select the appropriate one for the pupils to use and learn (S11);

We must take into consideration pupils' ability when choosing the right tools / resources (S48);

The problem of marking the package ICT based, which cannot be otherwise substituted with non-ICT tools (S57).

Finally, the last two items, designing tasks and defining roles for teachers and students, indicate preservice teachers' difficulty with scaffolding design. The notion of 
scaffolding, closely linked with the zone of proximal development (ZPD) by Vygotsky (1978), is viewed as the form of proving assistance to a learner to solve a problem or task that is beyond his or her current range of competence, but can be achievable with interaction with more capable people (e.g., parents, teachers, and peers) or through the mediation of tools. The technical dimension of scaffolding is that tools and resources (e.g., visualisation and modeling programs) can be used to help students learn independently by providing external and cognitive support (Pea, 2004). While participants in this study understood the importance of scaffolding in the PBL approach, they struggled with the extent of how and what to scaffold, as revealed in the open ended responses as well as the lesson design artifacts mentioned earlier. Participants' comments on scaffolding design include:

In order to design an effective task for pupils, we went through a lot of thoughts. We had difficulty designing a task that is not drill and practice yet at the same time, pupils can consolidate their learning from there (S50);

We had to strike a balance between making the tasks suitable for independent learning and at the same time provide scaffolds for them. In addition, the tasks had to be innovative and creative, thus we took a rather long period to finalise this aspect (S76); I wasn't sure how much information I was to give to the students and how much to let them find out on their own (S86).

\section{Perceived advantages and limitations of PBL and ICT integration}

Finally, we examined specific advantages and limitations that student teachers perceived about PBL and ICT integration. As summarised in Table 3, the analysis of survey responses indicates that participants perceived a number of advantages of employing student centred learning approaches, which were consistent with their understanding of PBL as constructivist pedagogy mentioned earlier.

Table 3: Perceived strengths and limitations of PBL and ICT

\begin{tabular}{|c|c|c|c|}
\hline Question & & Response & $f$ \\
\hline $\begin{array}{l}\text { What do you } \\
\text { see as the }\end{array}$ & Strength & $\begin{array}{l}\text { Students learn independently and are responsible for their own } \\
\text { learning. }\end{array}$ & 24 \\
\hline main strength & & Problems/tasks are interesting and innovative to students. & 17 \\
\hline and main & & $\begin{array}{l}\text { PBL stimulates critical thinking and forces them to think } \\
\text { creatively. }\end{array}$ & 16 \\
\hline & Limitation & $\begin{array}{l}\text { It is time-consuming to conduct PBL; a lot of time is involved in } \\
\text { solving problems / tasks. }\end{array}$ & 20 \\
\hline & & On teacher's part, it takes too much time to prepare PBL lessons. & 12 \\
\hline & & $\begin{array}{l}\text { PBL may not be effective with low ability students; PBL requires } \\
\text { certain level of maturity. }\end{array}$ & 9 \\
\hline $\begin{array}{l}\text { What do you } \\
\text { see as the }\end{array}$ & Strength & $\begin{array}{l}\text { Integrated visual aids (e.g. animation, video) make learning } \\
\text { interesting, engaging, and interactive. }\end{array}$ & 63 \\
\hline $\begin{array}{l}\text { main strength } \\
\text { and limitation }\end{array}$ & & $\begin{array}{l}\text { Technology integration can be adapted to students' different } \\
\text { learning styles. }\end{array}$ & 9 \\
\hline of integrating & & It promotes students to learn ICT tools. & 7 \\
\hline ICT tools into & Limitation & It is time-consuming to prepare and conduct the lesson. & 25 \\
\hline $\begin{array}{l}\text { your PBL } \\
\text { lesson? }\end{array}$ & & $\begin{array}{l}\text { It requires students to have enough IT skills and to have access to } \\
\text { Internet. }\end{array}$ & 20 \\
\hline & & It may cause technical problems. & 9 \\
\hline
\end{tabular}

Nonetheless, student teachers also perceived several limitations of applying such student centred approaches with ICT integration. Not surprisingly, time is the most 
critical factor for negative responses. Student teachers stated that designing and implementing PBL lessons is time consuming. A number of students perceived that PBL may not be appropriate for low achieving students since tasks require higher order problem solving skills. Their perceptions of ICT integration showed a similar pattern. While participants were able to see the benefits of integrating technology for teaching and learning, they reported that it is time consuming and requires IT skills from both students and teachers.

\section{Conclusion and implications}

The purpose of this study was to examine pre-service teachers' perceptions of TPCK and their cognitive difficulties in applying TPCK into actual lesson designs. Participants were engaged in a Collaborative Lesson Design project where they designed a content specific lesson based on their understanding of PBL and ICT integration. The main goal of this design project was to help students make intimate connections among content, pedagogy, and technology by designing a concrete lesson artifact with a partner. Survey data and lesson design artifacts were analysed to identify participants' understanding, perception, and application of TPCK.

On the whole, this study shows that while student teachers had good understandings of pedagogical knowledge on PBL, they experienced several difficulties applying their knowledge into designing a PBL based, technology integrated lesson. The areas that students perceived to be particularly challenging and difficult included:

a. generating authentic and ill-structured problems for a chosen content topic,

b. finding and integrating ICT tools and resources relevant for the target students and learning activities, and

c. designing tasks with a balance between teacher guidance and student independence.

Additionally, this study observed the discrepancy between pedagogical understanding of PBL and actual PBL lesson designs with ICT components, suggesting the complexity of believing, knowing, and doing related to teacher knowledge. Pre-service teachers in this study were able to understand the importance of PBL and ICT integration, and how such student centred pedagogy could help students learn higher order skills. However, actual lesson designs showed that pre-service teachers were not able to translate their beliefs and knowledge to create a pedagogically sound lesson package with integration of ICT components.

Then, an important question to ask is "why do pre-service teachers have such difficulties in designing an ICT integrated lesson?" The present study suggests the potential of two explanations:

a. lack of intimate connection among beliefs, knowledge, and actions, and

b. insufficient repertoires for teaching with technology for problem-based learning.

First, consistent with previous action theories on teacher practices (e.g., Argyris et al., 1985; Kane et al., 2002; Strauss, 1993), this study suggests that there might be two types of TPCK: espoused TPCK that teachers can talk about what pedagogically sound technology integration means for their subject matter, and in use TPCK that teachers can translate their beliefs and knowledge to design and implement a pedagogically sound, technology integrated lesson for their content areas. As shown in the results of 
this study, student teachers were able to understand the pedagogical approaches of PBL and what technology integration meant to them for teaching and learning (espoused TPCK), but had difficulties applying their beliefs and knowledge into designing pedagogically-sound technology-integrated lessons (in use TPCK). It should be noted that since the present study did not specifically examine personal beliefs underlying TPCK issues and the implementation of the designed lesson in actual classroom settings, the argument for the gap between espoused TPCK and in use TPCK is partially supported here. Further investigation of this issue is warranted.

Second, it is possible that pre-service teachers in this study did not have enough repertoires about teaching with technology for problem based learning in their subject areas. Studies on expert and novice teachers provide some insights into this lack of pre-service teachers' TPCK. For instance, Grossman (1990) found that expert teachers had a solid knowledge base of their content areas, student conceptual understanding and misconceptions, and effective teaching strategies. However, novice teachers were likely to have a superficial knowledge base, and could not see the interplay between content knowledge and pedagogical knowledge. Similar to this, the present study found that participants had a superficial pedagogical content knowledge of technology integration as revealed in their comments on the difficulty of finding relevant ICT tools and resources and the use of ICT as a simple delivery tool in the lesson design artifacts. While the Collaborative Lesson Design aimed to help student teachers make intimate connections among content, pedagogy, and technology in a collaborative way, obviously one single course on ICT integration is not sufficient to build a firm base of TPCK.

Based on findings, we can describe some implications for the current practices in teacher education. The complex and situated nature of TPCK necessitates approaches in which technology, pedagogy, and content knowledge are treated as an integrated body of knowledge. In order to resolve conflicts in content, pedagogical, and technological knowledge, pre-service teachers should be continuously exposed to new and innovative teaching practices with technology throughout their teacher training. Considering that most student teachers come to the teacher training programs with little previous exposure to student centred and technology integrated learning experiences, teacher education programs should be structured in a way that allows pre-service teachers to change their limited thinking within existing models of teaching and learning with technology. Possible ways to help pre-service teachers achieve deeper connections among content, pedagogical, and technological knowledge may include:

a. designing a series of integrated modules;

b. providing student teachers with situated practices for formative feedback and epistemological reflection related to their experiences for teaching and learning;

c. presenting various examples of subject-specific technology integrated lessons with their impacts on student learning.

A multi-dimensional approach taken in the teacher education program of Niess's (2005) study provides one good example of fostering a knowledge base of TPCK. This program implemented a series of technology integrated modules throughout the year, which were designed to guide pre-service teachers in designing and practicing technology integrated lessons. Moreover, a follow up module engaged pre-service teachers to reflect on their use of technology for teaching and learning, in particular in relation to the impact on student learning. Another example for strengthening a 
knowledge base of TPCK is the use of teacher inquiry (Dana \& Silva, 2003). Dawson (2006) witnessed that student teachers were able to integrate technology in a more desirable way and paid more attention to student learning outcomes resulting from technology integrated lessons, when they engaged in guided inquiry processes during technology enhanced field experiences.

More importantly, building a knowledge base of TPCK should be viewed as a long term trajectory that goes beyond pre-service teacher education in formal settings (Fishman \& Davis, 2006). As teachers gain more experience, they can continue to expand their knowledge base and to strengthen the connection between content, pedagogy and technology. To support this long term trajectory of teacher learning, TPCK issues should be addressed as "a continuum of coordinated efforts that range from pre-service education to early teaching to opportunities for lifelong development as professionals" (Bransford, Brown \& Cocking, 2002, p. 205). In conclusion, as Shulman (1986) stated that "those who can, do; those who understand, teach" (p.14), we suggest that teacher education should provide our student teachers with opportunities for deep understanding regarding pedagogically sound technology integration. A subject neutral and generic environment would not be successful in helping pre-service teachers to form a robust knowledge base for seeing the complex inter-relationships among content, pedagogy, and technology. Since content, pedagogical, and technological knowledge are all inter-related, this suggests that teacher education programs should be structured in a holistic manner to allow student teachers to see the connection.

\section{Acknowledgments}

Portions of this paper were presented at the International Conference for the Learning Sciences in 2006:

So, H.-J. \& Kim, B. (2006). Conflicts in pedagogical and technical knowledge: Pre-service teachers' understanding and misconception of integrating technology into PBL lessons. International Conference for the Learning Sciences 2006. http: / / www.lsl.nie.edu.sg/events / ICLS2006_Proceeding_DrSo.pdf

\section{References}

Angeli, C. (2004). The effects of case-based learning on early childhood pre-service teachers' beliefs about the pedagogical use of ICT. Journal of Educational Media, 29(2), 139-151.

Angeli, C., \& Valanides, N. (2005). Preservice elementary teachers as information and communication technology designers: An instructional systems design model based on an expanded view of pedagogical content knowledge. Journal of Computer Assisted Learning, 21, 292-302.

Argyris, C., Putnam, R. \& McLain Smith, D. (1985). Action science. San Francisco: Jossey-Bass.

Barab, S., Thomas, M., Dodge, T., Carteaux, R. \& Tuzun, H. (2005). Making learning fun: Question Atlantis, a game without guns. Educational Technology Research and Development, 53(1), 86-107.

Barak, M., \& Dori, Y. J. (2005). Enhancing undergraduate students' chemistry understanding through project-based learning in an IT environment. Science Education, 89(1), 117-139. 
Barron, J. S., Schwartz, D. L., Vye, N. L., Moore, A., Petrosino, A., Zech, L., et al. (1998). Doing with understanding: Lessons from research on problem- and project-based learning. Journal of the Learning Sciences, 7(3\&4), 271-311.

Bottino, R. M. \& Robotti, E. (2007). Transforming classroom teaching and learning through technology: Analysis of a case study. Educational Technology \& Society, 10(4), 174-186. http: / / www.ifets.info/others / download_pdf.php?j_id=37\&a_id=804

Bransford, J. D., Brown, A. L. \& Cocking, R. R. (2002). How people learn: Brain, mind, experience, and school. Washington, DC: National Academy Press. http: / / www.nap.edu/openbook.php?record_id=6160

Dana, N. F., \& Silva, D. Y. (2003). The reflective educator's guide to classroom research: Learning to teach and teaching to learn through practitioner inquiry. Thousand Oaks, CA: Corwin Press.

Dawson, K. (2006). Teacher inquiry: A vehicle to merge prospective teachers' experience and reflection during curriculum-based, technology-enhanced field experiences. Journal of Research on Technology in Education, 38(3), 265-292.

Ertmer, P. A. (2005). Teacher pedagogical beliefs: The final frontier in our quest for technology integration. Educational Technology Research and Development, 53(4), 25-39.

Fang, Z. (1996). A review of research on teacher beliefs and practices. Educational Research, 38(1), 47-65.

Ferdig, R. E. (2006). Assessing technologies for teaching and learning: Understanding the importance of technological pedagogical content knowledge. British Journal of Educational Technology, 37(5), 749-760.

Fishman, B. \& Davis, E. (2006). Teacher learning research and the learning sciences. In R. K. Sawyer (Ed.), Cambridge handbook of the learning sciences (pp. 535-550). Cambridge: Cambridge University Press.

Grossman, P. (1990). The making of a teacher. New York: Teachers College Press.

Hew, K. F. \& Brush, T. (2007). Integrating technology into K-12 teaching and learning: Current knowledge gaps and recommendations for future research. Educational Technology Research and Development, 55(3), 223-252.

Hollingsworth, S. (1989). Prior beliefs and cognitive change in learning to teach. American Educational Research Journal, 26(2), 160-189.

Hughes, J. (2005). The role of teacher knowledge and learning experiences in forming technology-integrated pedagogy. Journal of Technology and Teacher Education, 13(2), 277-302.

Kane, R., Sandretto, S. \& Heath, C. (2002). Telling half the story: A critical review of research on the teaching beliefs and practices of university academics. Review of Educational Research, $72(2), 177-228$

Kearney, M. (2006). Prospective science teachers as e-learning designers. Australasian Journal of Educational Technology, 22(2), 229-250. http: / / www.ascilite.org.au/ajet/ajet22/ kearney2.html

Keating, T. \& Evans, E. (2001). Three computers in the back of the classroom: Pre-service teachers' conceptions of technology integration. Paper presented at the annual meeting of the American Educational Research Association, Seattle, WA.

Koehler, M. J. \& Mishra, P. (2005). What happens when teachers design educational technology? The development of technological pedagogical content knowledge. Journal of Educational Computing Research, 32(2), 131-152. 
Koehler, M., J., Mishra, P. \& Yahya, K. (2007). Tracing the development of teacher knowledge in a design seminar: Integrating content, pedagogy and technology. Computers $\mathcal{E}$ Education, 49, 740-762.

Linn, M. C., Clark, D. \& Slotta, D. (2003). WISE design for knowledge integration. Science Education, 87, 517-538.

Mehlinger, H. D. \& Powers, S. M. (2002). Technology and teacher education: A guide for educators and policymakers. Boston: Houghton Mifflin.

Mishra, P. \& Koehler, M., J. (2006). Technological pedagogical content knowledge: A framework for teacher knowledge. Teachers College Record, 108(6), 1017-1054.

Moursund, D. \& Bielefeldt, T. (1999). Will new teachers be prepared to teach in a digital age? A national survey on information technology in teacher education. Milken Family Foundation. [viewed 14 June 2003, verified 2 Feb 2009] http:/ / www.mff.org/pubs/ME154.pdf

Niess, M. L. (2005). Preparing teachers to teach science and mathematics with technology: Developing a technology pedagogical content knowledge. Teaching and Teacher Education, 21, 509-523.

Pea, R. D. (2004). The social and technological dimensions of scaffolding and related theoretical concepts for learning, education, and human activity. Journal of the Learning Sciences, 13(3), 423-451.

Pierson, M. E. (2001). Technology integration practice as a function of pedagogical expertise. Journal of Research on Computing in Education, 33(4), 413-430.

Riel, M. M. \& Becker, H. J. (2000). The beliefs, practices, and computer use of teacher leaders. Paper presented at the annual meeting of the American Educational Research Association, New Orleans.

Roschelle, J., Kaput, J. \& Stroup, W. (2000). SimCalc: Accelerating student engagement with the mathematics of change. In M. J. Jacobson \& R. B. Kozma (Eds.), Learning the sciences of the 21st century: Research, design, and implementing advanced technology learning environments (pp. 4775). Mahwah, NJ: Lawrence Erlbaum Associates.

Scardamalia, M. \& Bereiter, C. (1994). Computer support for knowledge-building communities. The Journal of Learning Sciences, 3(3), 265-283.

Shulman, L., S. (1986). Those who understand: Knowledge growth in teaching. Educational Researcher, 15(2), 4-14.

Shulman, L. S. (1987). Knowledge and teaching: Foundations of the new reform. Harvard Educational Review, 51, 1-22.

Strauss, S. (1993). Teachers' pedagogical content knowledge about children's minds and learning: Implications for teacher education. Educational Psychologist, 28(3), 279-290.

van Aalst, J. \& Chan, C. K. K. (2007). Student-directed assessment of knowledge building using electronic portfolios. The Journal of the Learning Sciences, 16, 175-220.

Vannatta, R. A. \& Beyerbach, B. (2000). Facilitating a constructivist vision of technology integration among education faculty and pre-service teachers. Journal of Research on Computing in Education, 33(2), 132-148.

Vygotsky, L. S. (1978). Mind and society: The development of higher mental processes. Cambridge, MA: Harvard University Press. 
White, B. Y. \& Frederiksen, J. R. (1998). Inquiry, modeling, and metacognition: Making science accessible to all students. Cognition and Instruction, 16(1), 3-118.

Willis, J. \& Mehlinger, H. D. (1996). Information technology and teacher education. In J. Sikula (Ed.), Handbook of research on teacher education (pp. 978-1029). New York: Macmillan.

Windschitl, M. \& Sahl, K. (2002). Tracing teachers' use of technology in a laptop computer school: The interplay of teacher beliefs, social dynamics, and institutional culture. American Educational Research Journal, 39(1), 165-205.

Zhao, Y., Pugh, K. \& Sheldon, S. (2002). Conditions for classroom technology innovations. Teachers College Record, 104(3), 482-515.

Dr Hyo-Jeong So is currently an assistant professor in the Learning Sciences and Technologies Academic Group at the National Institute of Education, Nanyang Technological University, in Singapore. Her research interests include computer supported collaborative learning, technology integration in K-12 classrooms, teachers' epistemological beliefs about teaching and learning, and seamless mobile learning. Email: hyojeong.so@nie.edu.sg

Bosung Kim is a doctoral candidate at the School of Information Science and Learning Technologies, University of Missouri, Columbia, USA. Email: bkq22@mizzou.edu 